\title{
LGMD phenotype due to a new gene and dysferlinopathy investigated by next-generation sequencing
}

\section{OPEN}

Correspondence to Dr. Angelini: corrado.angelini@unipd.it

\section{Neurol Genet}

2015;1:e39; doi: 10.1212/ NXG.0000000000000039

\section{See articles}

In this issue of Neurology ${ }^{\circledR}$ Genetics, Endo et al. ${ }^{1}$ report 3 cases of limb-girdle muscular dystrophy (LGMD) phenotype with mental retardation or hyperCKemia found by next-generation sequencing (NGS) to have a variant in the POMGNT2 gene, which has so far been recognized only as causing congenital muscular dystrophy (CMD).

The glycosyl transferases participate in $\alpha$-dystroglycan glycosylation and form $\alpha$-dystroglycan-dystrophin complex. The deficiency in many glycosyl transferases causes both CMD and LGMD phenotypes. In this particular transferase, there was only a report of a severe Walker-Warburg syndrome described by Manzini et al. ${ }^{2}$ It is notable that onset was early in these new LGMD cases, occurring in the first years in 2 cases, with low IQ, resolved developmental delay, and walking ability.

This issue also reports the use of NGS by Izumi et $\mathrm{al}^{3}$ in a series of LGMD/distal myopathies, both with a phenotype of dysferlinopathy (i.e., teenage-toadult-onset myopathy, with high creatine kinase and no cardiac abnormalities) and in previously diagnosed persons in whom dysferlin gene mutations have been already identified by the single-strand conformation polymorphism method. This NGS screening resulted in the identification of 12 new dysferlinopathy cases and 9 cases with calpain- 3 gene mutations.

The only limitation of this NGS screening is the lack of validation on messenger RNA (mRNA) because muscle samples were not available due to the great East Japan earthquake.

The term $L G M D$ defines a progressive weakness with onset in the proximal limb-girdle muscles, with age at onset of symptoms varying from early childhood (not congenital) to late adulthood. The progression of muscle weakness is usually symmetrical and variable among individuals and genetic type. The term $L G M D$, used to molecularly classify the disease, is, however, inappropriate for many patients when it is used to describe the clinical severity. Indeed, these disorders present a wide spectrum of muscle involvement and wasting, spanning from very severe forms, such as those with childhood onset and rapid progression, to relatively benign forms with late onset.

The clinical phenotypes due to mutation in the LGMD genes include severe childhood-onset forms, distal and proximal myopathies, pseudometabolic myopathies, eosinophilic myositis, and hyperCKemia. Furthermore, patients with a clinically typical LGMD phenotype might carry mutations in the gene encoding emerin, which usually cause Emery-Dreifuss muscular dystrophy (EDMD) phenotype. Because there is a spectrum of phenotypes under the same genetic entity and a wide genetic heterogeneity under the same phenotype, it is crucial to identify suitable selection criteria to be used when screening patients for the proteins and genes responsible for LGMD.

As LGMD is relatively rare in most populations, other more likely diagnoses need to be excluded. Among these, dystrophinopathies (Duchenne dystrophy, Becker dystrophy, and female carriers of Duchenne dystrophy) are the most relevant, and these diagnoses can be ruled out based on dystrophin protein testing and/or DNA mutation analysis in the dystrophin gene. Another diagnosis that can usually be resolved by DNA analysis is facioscapulohumeral muscular dystrophy (FSHD): about $8 \%$ of patients with a diagnosis of LGMD may actually have FSHD, and the misdiagnosis can occur in families with autosomal dominant inheritance, especially when both pelvic and shoulder girdles are involved and facial weakness is minimal. Molecular investigation to exclude FSHD is worthwhile, especially in patients with a positive family history. EDMD, which is characterized by the triad of joint contractures of early onset, slowly progressive muscle weakness, and cardiac involvement, may be due to mutations in the emerin gene (X-linked) or in the lamin $\mathrm{A} / \mathrm{C}$ gene (autosomal dominant, allelic with LGMD1B). Additional differential diagnoses may be inflammatory myopathies, myofibrillar myopathies, and metabolic

From the Neuromuscular Center, Fondazione San Camillo Hospital IRCCS, Lido Venice, Italy.

Funding information and disclosures are provided at the end of the editorial. Go to Neurology.org/ng for full disclosure forms. The Article Processing Charge for this editorial was waived at the discretion of the Editor.

This is an open access article distributed under the terms of the Creative Commons Attribution-NonCommercial-NoDerivatives License 4.0 (CC BY-NC-ND), which permits downloading and sharing the work provided it is properly cited. The work cannot be changed in any way or used commercially. 
myopathies, which can also be excluded on the basis of muscle histopathology. Muscle imaging (CT scan and MRI) may be helpful to characterize the severity and the pattern and distribution of muscle wasting. The milder the symptoms, the more difficult the diagnosis.

The new NGS technique yields considerable advancement and allows the diagnosis of LGMD and hyperCKemia, making it a powerful technique for practitioners. However, its cost-effectiveness has yet to be demonstrated, because in the case of known genes such as dysferlin, if muscle is available, it is preferable to perform dysferlin Western blotting, which is specific in all cases in which a severe protein defect is detected. ${ }^{4}$ In fact, the recent American Academy of Neurology guidelines for LGMD suggest the use of NGS as a last resort. ${ }^{5}$

Moreover, in dysferlinopathy, one does not need muscle tissue because the dysferlin protein can also be studied in monocytes by Western blotting, followed by multiplex ligation-dependent probe amplification analysis of the gene. Therefore, here again, analysis of dysferlin mRNA can be helpful for distinguishing symptomatic heterozygotes from affected patients. ${ }^{6}$

\section{STUDY FUNDING}

No targeted funding reported.

\section{DISCLOSURE}

C. Angelini has served on scientific advisory boards for Neuromuscular Disorders, Neurological Sciences, Current Opinion of Neurology, Neurology, and Therapeutic Advances in Neurological Disorders; has received funding for travel and/or speaker honoraria from Genzyme European Register; has served on the editorial boards of Neuromuscular Disorders, Neurological Sciences, Current Opinion of Neurology, Neurology, and Therapeutic Advances in Neurological Disorders; and has received research support from Genzyme, Telethon, and the Association Francaise contre les Myopathies. Go to Neurology.org/ng for full disclosure forms.

\section{REFERENCES}

1. Endo Y, Dong M, Noguchi S, et al. Milder forms of muscular dystrophy associated with POMGNT2 mutations. Neurol Genet 2015;1:e33. doi: 10.1212/NXG. 0000000000000033.

2. Manzini MC, Tambunan DE, Hill RS, et al. Exome sequencing and functional validation in zebrafish identify GTDC2 mutations as a cause of Walker-Warburg syndrome. Am J Hum Genet 2012;91:541-547.

3. Izumi R, Niihori T, Takahashi $\mathrm{T}$, et al. Genetic profile for suspected dysferlinopathy identified by targeted next-generation sequencing. Neurol Genet 2015;1:e36. doi: 10.1212/ NXG.0000000000000036.

4. Cacciottolo M, Numitone G, Aurino S, et al. Muscular dystrophy with marked dysferlin deficiency is consistently caused by primary dysferlin gene mutations. Eur J Hum Genet 2011;19:974-980.

5. Narayanaswami P, Weiss M, Selcen D, et al. Evidence-based guideline summary: diagnosis and treatment of limb-girdle and distal dystrophies: report of the guideline development subcommittee of the American Academy of Neurology and the practice issues review panel of the American Association of Neuromuscular \& Electrodiagnostic Medicine. Neurology 2014;83:1453-1463.

6. Meznaric M, Gonzalez-Quereda L, Gallardo E, et al. Abnormal expression of dysferlin in skeletal muscle and monocytes supports primary dysferlinopathy in patients with one mutated allele. Eur J Neurol 2011;18:1021-1023. 


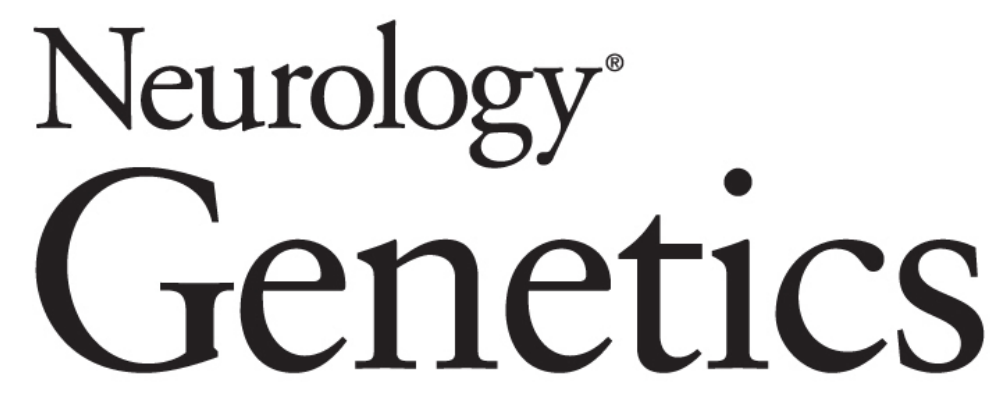

\section{LGMD phenotype due to a new gene and dysferlinopathy investigated by next-generation sequencing \\ Corrado I. Angelini \\ Neurol Genet 2015;1; \\ DOI 10.1212/NXG.0000000000000039}

\section{This information is current as of December 10, 2015}

\section{Updated Information \&} Services

References

Citations

Permissions \& Licensing

Reprints including high resolution figures, can be found at: http://ng.neurology.org/content/1/4/e39.full.html

This article cites 6 articles, 2 of which you can access for free at: http://ng.neurology.org/content/1/4/e39.full.html\#\#ref-list-1

This article has been cited by 1 HighWire-hosted articles: http://ng.neurology.org/content/1/4/e39.full.html\#\#otherarticles

Information about reproducing this article in parts (figures,tables) or in its entirety can be found online at:

http://ng.neurology.org/misc/about.xhtml\#permissions

Information about ordering reprints can be found online: http://ng.neurology.org/misc/addir.xhtml\#reprintsus

Neurol Genet is an official journal of the American Academy of Neurology. Published since April 2015, it is an open-access, online-only, continuous publication journal. Copyright (C) 2015 American Academy of Neurology. All rights reserved. Online ISSN: 2376-7839.

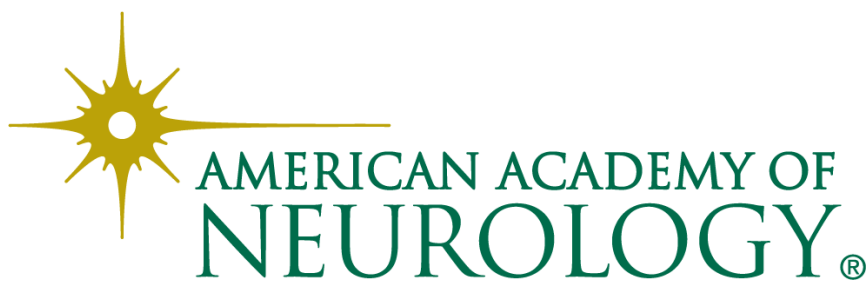

